Sains Malaysiana 49(8)(2020): 1947-1950

http://dx.doi.org/10.17576/jsm-2020-4908-16

\title{
Effect of Halal and Non-Halal Slaughtering Methods on Bacterial Contamination of Poultry Meat
}

(Kesan Cara Penyembelihan Halal dan Tidak Halal Kepada Pencemaran Bakteria Daging Ayam)

\author{
LOKMAN IDris Hakim, Nur Mahiza Md. IsA, Shahira Mohd TAHIR \& EMmanuel Busayo IBITOYE*
}

\begin{abstract}
This study was designed to investigate and compare the effect of halal (Islamic rules) and non-halal (non-Islamic rules) slaughtering methods on the quality characteristics of chicken. Ten village chickens weighing 0.9 - $1 \mathrm{~kg}$ of the same age and farm management were involved; five of them were slaughtered using the halal method, while the other five were slaughtered using the non-halal method by cutting only one side of the jugular vein and carotid artery. Bleeding time, death time, the volume of blood loss, microbial count of Standard Plate Count (SPC) and Coliform Plate Count $(C P C)$ were determined immediately at and post-slaughtering. There was no significant difference in the microbial count of CPC between both slaughtering methods. Bleeding time, death time and SPC results for non-halal slaughtered chickens were significantly $(\mathrm{p}<0.05)$ higher than the halal slaughtered chickens, while the volume of blood lost was found significantly $(\mathrm{p}<0.05)$ lower for non-halal slaughtered chickens. These data suggested that non-halal slaughtered chickens could contain more residual blood in the meat that can lead to an increase in bacterial counts, consequently shortened shelf life.
\end{abstract}

Keywords: Chicken meat; halal slaughter; microbial count; residual blood; village chicken

ABSTRAK

Kajian ini dijalankan untuk mengkaji dan membandingkan kesan kaedah penyembelihan secara halal (hukum Islam) dan tidak halal (hukum bukan Islam) kepada kualiti ayam. Sepuluh ekor ayam kampung dengan berat 0.9 - $1 \mathrm{~kg}$ pada usia serta pengurusan yang sama terlibat dalam kajian ini; lima daripadanya disembelih secara halal, manakala selebihnya disembelih secara tidak halal dengan memotong vena jugulum dan arteri karotid. Tempoh pendarahan, waktu kematian, isi padu kehilangan darah, kiraan mikrob berdasarkan Kiraan Plat Piawai (SPC) dan Kiraan Plat Koliform (CPC) ditentukan pada dan pasca penyembelihan. Tidak terdapat perbezaan signifikan pada kiraan mikrob CPC antara kedua-dua kaedah penyembelihan. Tempoh pendarahan, waktu kematian dan keputusan SPC untuk penyembelihan tidak halal adalah signifikan $(\mathrm{p}<0.05)$ iaitu tinggi daripada penyembelihan ayam secara halal, isi padu kehilangan darah pula didapati secara signifikannya $(\mathrm{p}<0.05)$ rendah bagi ayam yang disembelih secara tidak halal. Data ini menunjukkan ayam yang disembelih secara tidak halal mempunyai lebihan darah yang lebih tinggi pada dagingnya yang menyebabkan peningkatan kiraan bakteria yang seterusnya memendekkan hayat simpanannya.

Kata kunci: Ayam kampung; daging ayam; kiraan mikrob; lebihan darah; penyembelihan halal

\section{INTRODUCTION}

Chicken meat generally refers to either the whole carcasses or parts of the carcass or boned out meat of the species Gallus gallus and it is consumed by many people globally (Darshana et al. 2014). This is because the poultry meat is highly valued among the multiethnic populace; it has no religious prohibition unlike beef and pork that are forbidden among some races or religions. The consumption of poultry products continues to increase every year, this was attributed to higher demands, consumers' desire for safe and quality products, without pathogenic microorganisms contamination (Rouger et al. 2017). Slaughtering is the most crucial stage in the transformation of an animal into wholesome meat (Nakyinsige et al. 2013). Slaughtering is any procedure that causes the death of an animal by bleeding (Shimshony \& Chaudry 2005). Factors such as an individual's tradition, belief system, ritual, and a country's legislation can influence slaughtering methods. All the methods address the manner in which the animal is killed and bled, to some extent dressed and handled prior to human consumption.

Slaughtering involves the severing of the trachea; oesophagus; both the carotid arteries; jugular veins 
and it can be either non-halal or halal methods. In the non-halal method, the animal is rendered completely unconsciousness, while ritualistic or religious method mostly requires the animal to be conscious at the time of slaughtering (Department of Islamic Development Malaysia 2011). Alvarado et al. (2007) stated that residual blood is often associated with a meaty flavour and decreased shelf life due to bacterial contamination, commonly; Salmonella, Campylobacter, Staphylococcus aureus, E. coli and Listeria. This is because meat and blood are perfect media for bacterial growth as they are high in moisture content, minerals, vitamins, nitrogenous compounds such as essential amino acids and proteins as well as other growth factors (Darshana et al. 2014). In poultry processing, inadequate slaughtering is a common occurrence and it can lead to many other related problems (Gregory 2005), such as decreased blood loss and elongation of time to die (Alvarado et al. 2007). The chicken possibly enters the scalding tank alive and die due to suffocation (Shahdan et al. 2016). However, the halal slaughtering method maximally minimizes residual blood in the carcass and meat helping to elongate the shelf life, while non-halal slaughter method could lead to high residual blood that can cause lower meat wholesomeness. This study, therefore, aims to evaluate the association between the bacterial contaminations of poultry meat and halal or non-halal slaughtering methods. This is important, as it will provide information on the effect of halal and nonhalal slaughtering methods on bacterial contamination of poultry meat and the formulation of appropriate policy in the meat industry.

\section{MATERIALS AND METHODS}

Ten 60 days old village/indigenous chicken fed with commercial poultry pellets were randomly selected and evenly divided into groups A (halal slaughtering) and B (non-halal slaughtering) for this study. The birds were preconditioned prior to the experiment, whereby they were weighed, relaxed and fasted for $12 \mathrm{~h}$ but the water was provided. Birds in group A were slaughtered according to a halal method by severing both of the jugular vein and carotid artery and trachea while they were still conscious, while in group B were slaughtered using the non-halal method by cutting only one side of the jugular vein and carotid artery. Bleeding time ( $\mathrm{min}$ ), death time (min) and volume of blood loss ( $\mathrm{mL}$ ) during slaughtering for each chicken were recorded. Bleeding time was recorded as soon as the neck cutting started until last the drop of blood oozed from the bleeding point. The time of death of the chicken was observed by checking the pupillary and corneal reflex using a feather. The absence of movement also is observed to ensure the chicken is dead, while blood was drained into a $250 \mathrm{~mL}$ beaker. De-feathering and evisceration processes were done manually.

Aseptically, $25 \mathrm{~g}$ breast muscle or meat (M. Pectoralis major) was sampled in triplicate per chicken at $2 \mathrm{~h}$ interval starting from 0,2 nd and 4 th $\mathrm{h}$. For the 0 -h period, bacterial contamination analysis of the meat was directly done after weighing of the meat. For the 2 nd and 4th $\mathrm{h}$ period, samples were left opened in a sterile petri dishes under the same environmental condition at room temperature. For bacterial contamination of the meat, Standard Plate Count (SPC) and Coliform Plate Count (CPC) were done. For SPC, $25 \mathrm{~g}$ of the meat sample was placed in sterile 'stomacher' bag. $225 \mathrm{~mL}$ of peptone water was added into the bag. The meat was homogenized using a stomacher for $30 \mathrm{~s}$. This produced a $10^{-1}$ dilution. Five sterile bottles, which contain $9 \mathrm{~mL}$ of peptone water were labelled as $\# 2, \# 3, \# 4, \# 5$, and $\# 6$, in addition, six SPC plates were labelled as \#1 until \#6. Then $1 \mathrm{~mL}$ of $10^{-1}$ dilution was transferred into \#2 bottle using a sterile pipette and the contents were mixed. This produced $10^{-2}$ dilution. Using a new sterile pipette, $1 \mathrm{~mL}$ from \#2 bottle was transferred to \#3 bottle and mix. This also produced $10^{-3}$ dilution. The procedure was repeated for bottles \#4, $\# 5$, and \#6 to produce $10^{-4}, 10^{-5}$ and $10^{-6}$, respectively. Next, transfer $0.1 \mathrm{~mL}$ aliquot of dilution $10^{-1}$ onto \#1 labelled SPC agar plate. The aliquot was spread evenly using a sterile glass spreader and the plate was closed. This was repeated for \#2 until \#6 plates using $10^{-2}$ to $10^{-6}$ dilutions, respectively. The plates were allowed to dry at least for $15 \mathrm{~min}$ and were inverted and incubated at $35{ }^{\circ} \mathrm{C}$ for $48 \mathrm{~h}$. In CPC, dilutions from SPC analysis were used for plating. Six empty sterile petri dishes were labelled as \#1 until \#6. One $\mathrm{mL}$ aliquot of each dilution of $10^{-6}$ to $10^{-6}$ was transferred to the respective petri dish. Violet Red Bile agar (VRBA) that was maintained at 45 ${ }^{\circ} \mathrm{C}$ was added and swirled the filled petri dish. The plates were closed and allowed to cool and solidify. The plates were inverted and incubated at $35^{\circ} \mathrm{C}$ for $24 \mathrm{~h}$. After the incubation period, all bacteria colonies $(\mathrm{cfu} / \mathrm{g})$ on both SPC and CPC plates were counted.

Data on bleeding time, death time and volume of blood loss and SPC count were analyzed using an independent T-test, while CPC count was analyzed using the Mann-Whitney $U$ test. The number of microbe $\mathrm{cfu} / \mathrm{g}$ were converted to $\log \mathrm{cfu} / \mathrm{g}$ prior to statistical analysis. The significance level used was $p<0.05$ level. All analysis was performed using IBM SPSS statistics 23 .

\section{RESULTS AND DISCUSSION}

It was observed from this study that (Table 1), the bleeding was significantly $(p<0.05)$ faster with halal method than with the non-halal method, a larger volume of blood was significantly $(\mathrm{p}<0.05)$ lost when birds were slaughtered using the halal method than with the non-halal slaughtering method, while birds died more quickly $(p<0.05)$ from halal slaughtering than when slaughtered using non-halal slaughtering.

Furthermore, from this experiment, the CPC count for the non-halal slaughtered chickens increased within time but not in halal slaughtered chickens. On the other hand, the halal slaughtering method significantly $(p<0.05)$ reduced the SPC of chickens, while SPC was 
significantly $(p<0.05)$ increased by the non-halal slaughtering (Table 2).

This experiment is consistent with an earlier study by Stevenson (1993) which shows that shorter bleeding and death times can be achieved by cutting both carotid arteries and jugular veins. In this experiment, $4 \%$ of blood loss was achieved within $100 \mathrm{~s}$ of bleeding time for halal slaughtered chicken. This finding also agrees with those of Nakyinsige et al. (2014), that halal slaughtering led to the loss of more blood than the non-halal method. This may be attributed to the bilateral cutting of the carotid arteries and jugular veins, the continuous pumping of the heart, the presence of tonic muscle contraction and clonic activity (Gregory 2005). This finding is in agreement with Gregory and Wotton (2007) as well, that animal dies faster by severing both carotid arteries and jugular veins. According to Meat Research Institute 1984 (Stevenson 1993), failure to cut both carotid arteries can add two min to the time taken to reach brain failure. A bird can retain consciousness up to $8 \mathrm{~min}$ when only one jugular vein is severed (Stevens \& Ridgway 1996). These statements agree with this study as the chicken of nonhalal slaughtered died much more slowly. According to the Department of Islamic Development Malaysia (2011), death of chicken can be identified by dropping head, dropped wings, absence of blood oozing from the cut ends of carotid arteries, fully dilated or closed conjunctiva, absence of pupillary or corneal reflexes and absence of all movements of the carcasses.
Our findings on the bacterial contamination using CPC are in line with the report of Nakyinsige et al. (2014), that there was no significant difference in the bacterial contamination of rabbit meat under $24 \mathrm{~h}$. They however attributed their findings to the physiological status of the animal at slaughter, the spread of contamination during slaughter and processing, the temperature and other conditions of storage. However, SPC shows to be more sensitive than $\mathrm{CPC}$ as meat from the halal process significantly had lower bacterial contamination than the non-halal process. This data supported a previous study by Ibrahim et al. (2014), which can be related to the higher volume of blood loss in the halal method. Efficient and proper bleeding reduces the total amount of blood retained in the meat, which would have favoured the multiplication of spoilage microorganisms and acts as a carrier for foodborne pathogens (Lerner 2009). Alvarado et al. (2007) also stated that residual blood is often associated with a meaty flavour and decreased shelf life due to bacterial contamination.

In conclusion, this study showed that halal and nonhalal slaughtering statistically influenced bleeding time, the volume of blood lost, death time, and SPC count. There is no direct effect of the slaughtering method on $\mathrm{CPC}$ count. These findings suggest that non-halal slaughtered chickens could contain higher bacterial counts that can lead to shorter shelf life. Higher bacterial count is mostly caused by more retained blood in the muscle.

TABLE 1. Effect of halal and non-halal slaughtering methods on bleeding time, the volume of blood loss and death time of village chickens

\begin{tabular}{lccc}
\hline \multicolumn{1}{c}{ Parameters } & \multicolumn{2}{c}{ Slaughtering methods } & $p$-value \\
& Halal method & Non-halal method & \\
\hline Bleeding time (min) & $1.40 \pm 0.54$ & $3.60 \pm 0.54$ & 0.000 \\
Volume of blood loss (mL) & $24.85 \pm 5.56$ & $6.86 \pm 2.59$ & 0.000 \\
Death time (min) & $2.60 \pm 0.55$ & $5.60 \pm 0.55$ & 0.000 \\
\hline
\end{tabular}

TABLE 2. Bacterial counts of meat from chicken slaughtered in halal and non-halal slaughtering methods

\begin{tabular}{|c|c|c|c|}
\hline \multicolumn{4}{|c|}{ Mean of calculated CPC (cfu/g) } \\
\hline \multirow[t]{2}{*}{ Time (h) } & \multicolumn{2}{|c|}{ Slaughtering methods } & \multirow[t]{2}{*}{$p$-value } \\
\hline & Halal method & Non-halal method & \\
\hline 0 & $8.9 \times 10^{4}$ & $9 \times 10^{4}$ & 0.700 \\
\hline 2 & $14 \times 10^{5}$ & $11 \times 10^{5}$ & 0.814 \\
\hline 4 & $22.4 \times 10^{5}$ & $28.1 \times 10^{5}$ & 0.751 \\
\hline \multicolumn{4}{|c|}{ Mean of calculated SPC (cfu/g) } \\
\hline \multicolumn{4}{|c|}{ Slaughtering methods } \\
\hline & Halal method & Non-halal method & \\
\hline 0 & $12.6 \times 10^{4}$ & $65.2 \times 10^{4}$ & 0.008 \\
\hline 2 & $21.4 \times 10^{4}$ & $88 \times 10^{4}$ & 0.000 \\
\hline 4 & $31.2 \times 10^{4}$ & $91.2 \times 10^{4}$ & 0.000 \\
\hline
\end{tabular}




\section{ACKNOWLEDGEMENTS}

The authors express their gratitude to the staff members of the Nutrition Laboratory, Faculty of Veterinary Medicine, Universiti Putra Malaysia (UPM) for their assistance in conducting this experiment.

\section{REFERENCES}

Alvarado, C.Z., Richards, M.P., Keefe, S.F.O. \& Wang, H. 2007. The effect of blood removal on oxidation and shelf life of broiler breast meat. Poultry Science 86: 156-161.

Darshana, B.B., Thyagarajan, D., Churchil, R.R. \& Punniamurthy, N. 2014. Bacterial pathogens in chicken meat: Review. International Journal of Life Sciences Research 2(3): 1-7.

Department of Islamic Development Malaysia (JAKIM). 2011. Malaysian Protocol for the Halal Meat and Poultry Productions. Accessed on 18 March 2018.

Gregory, N.G. 2005. Recent concerns about stunning and slaughter. Meat Science 70(3): 481-491.

Gregory, N.G. \& Wotton, S.B. 2007. Effect of slaughter on the spontaneous and evoked activity of the brain. British Poultry Science 27(2): 195-205.

Ibrahim, S.M., Abdelgadir, M.A. \& Sulieman, A.M.E. 2014. Impact of halal and non-halal slaughtering on the microbiological characteristics of broiler chicken meat and sausages. Food and Public Health 4(5): 223-228.

Lerner, P.T. 2009. Evaluation of haemoglobin and myoglobin in poultry slaughtered by stunning and kosher slaughter. Folia Veterinaria 53(1): 25-27.

Nakyinsige, K., Fatimah, A.B., Aghwan, Z.A., Zulkifli, I., Goh, Y.M. \& Sazili, A.Q. 2014. Bleeding efficiency and meat oxidative stability and microbiological quality of New Zealand White rabbits subjected to halal slaughter without stunning and gas stun-killing. Asian-Australasian Journal of Animal Sciences 27(3): 406-413.
Nakyinsige, K., Man, Y.C., Aghwan, Z.A., Zulkifli, I., Goh, Y.M., Bakar, F.A., Al-Kahtani, H.A. \& Sazili, A.Q. 2013. Stunning and animal welfare from Islamic and scientific perspectives. Meat Science 95(2): 352-361.

Rouger, A., Odile Tresse, I.D. \& Zagorec, M. 2017. Bacterial contaminants of poultry meat: sources, species, and dynamics. Microorganisms 5(3): 50 .

Shahdan, I.A., Regenstein, J.M., Shahabuddin, A.S.M. \& Rahman, M.T. 2016. Developing control points for halal slaughtering of poultry. Poultry Science 95(7): 1680-1692.

Stevens, R.W.C. \& Ridgway, G.J. 1996. A technique for bleeding chickens from the jugular vein. Poultry Science 45(1): 204205.

Stevenson, P. 1993. The Welfare at Slaughter of Broiler Chickens: A Compassion in World Farming Trust. Petersfield, Hants.

Shimshony, A. \& Chaudry, M.M. 2005. Slaughter of animals for human consumption. Revue Scientifique et Technique-Office International des Epizooties 24(2): 693-710.

Lokman Idris Hakim, Nur Mahiza Md. Isa \& Shahira Mohd Tahir Faculty of Veterinary Medicine

Universiti Putra Malaysia

43400 Serdang, Selangor Darul Ehsan

Malaysia

Emmanuel Busayo Ibitoye*

Department of Theriogenology and Animal Production Faculty of Veterinary Medicine

PMB 2346 Usmanu Danfodiyo University Sokoto

Nigeria

*Corresponding author; email: eb.ibitoye@gmail.com

Received: 15 January 2020

Accepted: 8 April 2020 